\title{
Tourist satisfaction with American continent airports
}

\author{
Semra Günay Aktaş*, Eşref Ay, Nevin Yavuz, Serkan Olgaç
}

Keywords:
American Continents
Airports,
Satisfaction Map,
Terminal Cleaning,
Queuing Times,
Terminal Seating Facilities,
Overall Satisfaction,
Spatial Autocorrelation.

Tourist satisfaction is very important in terms of destination loyalty as revisit and recommendation intentions. The development of airline transportation has led to an increase in the average time spent by tourists during the destination process by shortening the transportation time. The purpose of this study is to determine the spatial distribution of passenger satisfaction levels at airports in the Americas. For this purpose, data for determining tourist satisfaction has been obtained from two different platforms. In order to determine the general satisfaction level at the airports, the data of 904 airports where 30 or more users made comments were taken into consideration in the google map database. Satisfaction distribution and clustering regarding airports were evaluated with the data obtained from Google. Mapping analysis was conducted using the spatial analysis method to determine the satisfaction levels of the tourists. MapInfo 16 program was used for mapping analysis. Satisfaction levels from American airports vary between 2.5 and 4.7. In addition, whether the airport satisfaction is spatial autocorrelation has been tested using the GeoDa program. Analyzes have revealed that airport satisfaction creates spatial autocorrelation in America. It is observed that satisfaction is high in airports in the east and west of North America and low in the middle parts. Satisfaction for Central America has been found to be high in the west of the continent and low in the east. Satisfaction levels for South America are high in the northeast, northwest, and also southwest coasts, while it is low in other parts. This situation shows that airports located in certain regions of the continent have similar characteristics. Skytrax data were used to determine the variables affecting satisfaction at airports. Because there is no statistical difference between the general satisfaction values obtained from Skytrax and google platforms. In the study, the data of 58 airports, which are 30 or more evaluated in the Skytrax database, were used. Accordingly, the variables affecting general satisfaction were explained by airport cleanliness, seating capacity, and waiting times. In addition, it was determined that the independent variable that affects satisfaction the most is the waiting time in the queue. This situation shows that measures should be taken to reduce the waiting time in the queue to increase satisfaction at airports. As a result, it is important to determine tourist satisfaction, to evaluate the quality of current practices, and to identify improvement aspects. High overall satisfaction at airports will increase the likelihood of tourists to reuse these airports and recommend them to other passengers, and will positively affect destination loyalty.

Article History:

Submitted: 21.09 .2020

Accepted: 24.04 .2021 recommend them to other pass

Doi: https://doi.org/10.31822/jomat.2021-6-2-89

\section{Introduction}

The contributions of that the world became a common market and the transportation networks are improved resulted in a common lifestyle across the world where trips are more frequent and more comprehensive, and millions of people are on the move. The air transportation has become the most preferred transportation system among these trips, especially in touristic and business trips (Tuncer \& Gavcar, 2014: 193). Air transport plays an important role in facilitating increased destination access and paves the way for entirely new routes to operate (Graham et al., 2008; Koo et al., 2017), thus, expanding the scope of the tourism sector. Developed air transport resulted in shortened transportation time while increasing the time that

*Corresponding Author

Semra Günay Aktaş: Professor, ,Anadolu University, Eskişehir, Turkey, Email: sgunay26@gmail.com, Orcid Id: 0000-0001-6663-6827(iD

Eşref Ay: PhD Student, Anadolu University, Eskişehir, Turkey, Email: esrefay@gmail.com, Orcid Id: 0000-0003-4092-6425 (iD

Nevin Yavuz: Lecturer, Eskişehir Technical University, Eskişehir, Turkey, Email: neviny@eskisehir.edu.tr, Orcid Id: 0000-0002-82575355 (iD)

Serkan Olgaç: Lecturer, Anadolu University, Eskişehir, Turkey, Email: solgac@anadolu.edu.tr, Orcid Id: 0000-0002-9539-9055 ii 
tourists spend within the destination. Besides, air transport connected far destinations to each other, and hence far destinations were opened to tourism sector, resulting an expanded tourism market (Tan, 2008: 24). Khan et al. (2017) concluded in their study that air transport has a quite significant effect in creating tourism demand. Newly opened destinations and new tourism types, on the other hand, increased the demand for air transport (Dimitriou \& Aparicio, 2018). This interdependency between tourism and aviation along with the increase in competition has transformed airports (Wiltshire, 2017).

The airports provide physical and social environment where all parties come together to produce air transport services (Kuyucak, 2007). Today, airports are considered all-purpose service units and are built and managed in a way to serve this purpose (Tan, 2008). Airports that provide services to ensure exchange between air and land transportation modes are divided into two areas, namely flight line (airside) and terminal line (landside). Passenger terminals are the most important areas of the landside. Passenger terminals are the areas where check-in, security and customs controls, and luggage processes are carried out for the passengers, while providing waiting and transfer, shopping and other possibilities between the flights and serving as an entrance gate to the country most of the time (Kuyucak, 2007: 19). They are also the first meeting point, with the destination in question, of the passenger visiting that country or city or the last place of impression (Kazda \& Caves, 2000: 245). Airports have key roles in the entrance to the country and represent the prestige of their country (Douglas et al., 2001: 224). As they are also the start and end point of the tourists' trips, the airports are the first place that tourists will form an impression regarding the vacation experience in the relevant destination. Thus, airport-services satisfaction takes an important place in vacationexperience satisfaction. Effective and efficient planning of airport functions will minimize the time that tourists spend for basic and compulsory services, increase the time period that they can make expenses, and both increase the quality of service experienced and improve the expense amount per person (Rendeiro \& Cesar, 2006: 874).

Today, airports as all-purpose enterprises have become significant centers for employment, shopping, commerce, business meetings and entertainment. Thus, rather than being an important tool to access a tourism destination, they became a tourism destination themselves. Especially airports in Asia started to transform into airport cities (Aerotropolis). Influencing other continents and countries, this transformation in Asian airports has created a new competitive environment (Sezgin \&Yavuz, 2018: 69).

The most important developments in air transportation with the effect of globalization can be divided into two as technological and structural changes. Passengers' expectations for service quality differ, especially as a result of the structural changes. Therefore, the perceived service quality and satisfaction of passengers are significantly affected by airport operations (Okumuş \& Asil, 2007).

The half of the world's new air traffic is expected to be inside or outside the Asia Pacific region over the next two decades. Besides, the growth in air transport is expected to be driven mainly by regions such as Asia Pacific, the Middle East and Latin America over the next five years. Air transport growth for the next five years is thought to be mainly driven by regions such as Asia Pacific, the Middle East and Latin America (European Commission, 2011). Therefore, the researcher aimed to examine the airport satisfaction spatially. The outcomes of this study are thought to contribute to the joint assessment and comparison of all airports.

The main purpose of this study is to determine the spatial distribution of satisfaction levels with passengers related to airports in America Continents.

The answers to the following questions were investigated in the study.

1. What is the distribution of passengers' satisfaction with the airports of the Americas?

2. Is there any spatial autocorrelation of passengers' satisfaction with the airports of the Americas?

3. What are the main factors that affect the overall satisfaction in the airports of the Americas?

4. Is there any difference between the opinions on the perceived overall satisfaction that were obtained from different databases with regard to the airports of the Americas?

The results of this study are important since they will contribute to the evaluation and comparison of all airports in America Continents. 


\section{Literature Review}

The satisfaction and dissatisfaction perceived by the passengers with the services provided directly affects the service quality and customer satisfaction of the airport. Therefore, knowing to what extent the services offered to passengers affect customer satisfaction and making the necessary plans and strategies in this direction is an important step in ensuring customer satisfaction (Çolak \& Doğan, 2015: 517). Besides, the overall satisfaction has a positive effect on the intention to reuse and the willingness to recommend the airport to others. As the passengers are satisfied with the services, they use them more and are more likely to recommend them to others (Kim et al., 2016: 156).

For this reason, many studies have been conducted in this area to understand the overall satisfaction level of passengers at different airports as well as the degree of commitment of tourists to the destination. For instance, Işlldak and Tunca (2018) identified factors affecting customer satisfaction in airport services. Factors affecting customer satisfaction are as follows: terminal personnel, terminal environment and finding routes, terminal facilities, reliable and accurate service, terminal conditions, demand and instant service, advantage and comfort, internet access and terminal's physical functionality. Chao, Lin, and Chen (2013) emphasized the importance of the physical properties of the terminal in order to improve the service quality at Kaohsiung International Airport. Bogicevic et al. (2013) conducted researches in 33 airports. The findings show that airport cleanliness is the key to passenger satisfaction. In their study, Moon et al. (2017) concluded that four variables, namely airport's physical environment, aesthetics of the facility, accommodation accessibility, seating comfort and cleanliness are the main determinants of customer satisfaction. Park and Jung (2011) conducted a study on the airport service quality perceptions of transfer passengers at Incheon International Airport and found that passengers who are satisfied with the airport service quality are more likely to reuse the airport and recommend it to other passengers.

Aşık (2019) investigated whether there is a difference in service quality perceptions and quality perception according to domestic and foreign passengers at Istanbul Airport. According to the results of the research, the quality perception of domestic and foreign passengers has been gathered under seven factors. These are respectively; physical characteristics, employee characteristics, speed and timing, transportation and direction finding, trust, price, and complimentary services. However, it has been concluded that the perception of the performance of domestic and foreign passengers differs for all service dimensions except transportation and direction finding and complimentary services.

Erdoğan (2020) evaluated airport services under 8 dimensions in his study to determine the service quality of Gaziantep Airport. These are check-in and baggage services, terminal ambiance, transportation, in-terminal mobility, shopping facilities, price, terminal facilities, and security. The Importance-Performance matrix was created by applying the Importance-Performance analysis for the determined service criteria. According to the results of the Importance-Performance analysis, services that need to be concentrated, protected, low priority, and possible excesses are determined separately. As a result of the analysis, it has been determined that the services in the cell that should be concentrated are not services that are not under the direct control of the airport management.

Günay Aktaş et al. (2020) determined the main factors affecting the satisfaction distribution and general satisfaction of 45 airports with the most flights in the Asian continent using Skytrax data. According to the research results, seating capacity, waiting time, and satisfaction with cleaning explain the general satisfaction. In particular, queuing time has been the most important factor affecting overall satisfaction at airports.

Yavuz et al. (2020) revealed the general satisfaction of the 100 airports with the highest number of passengers in Europe using Skytrax data and explained the general satisfaction level with other satisfaction levels. In the research, airport ownership, seating capacity, cleaning, queuing time, and the number of passengers was determined as variables that explain general satisfaction. Although airport ownership and the number of passengers do not have a statistically significant effect on overall satisfaction, it has been observed that queuing time is the main factor in explaining overall satisfaction at European airports.

\section{Method}

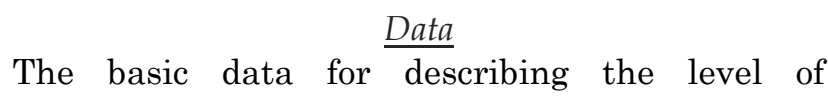
satisfaction with airports of the America Continents were derived from google maps. 904 airports were found to evaluated by 30 and above 


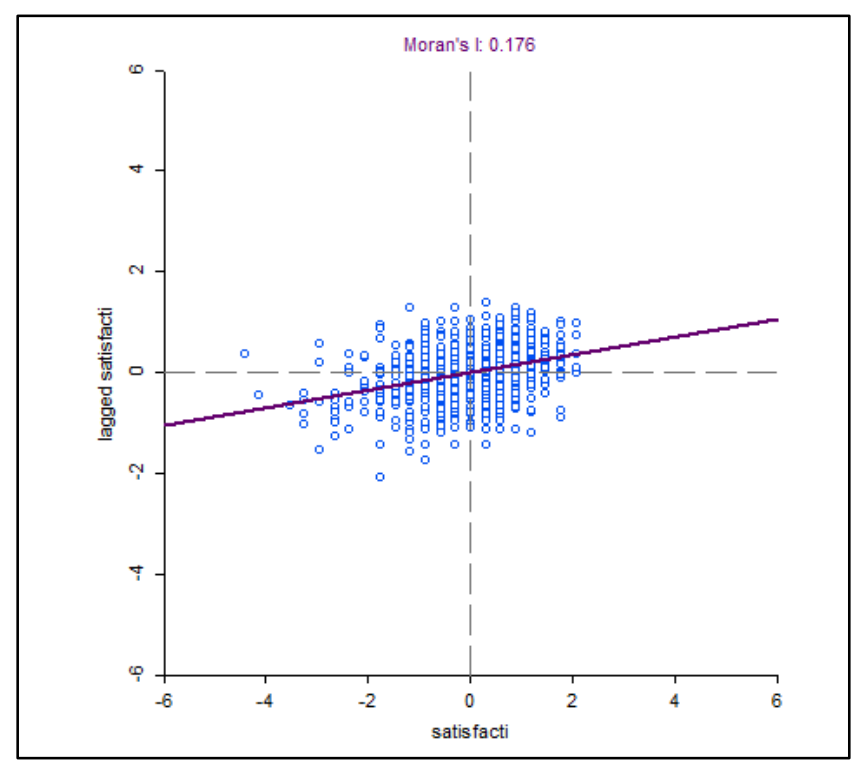

a)

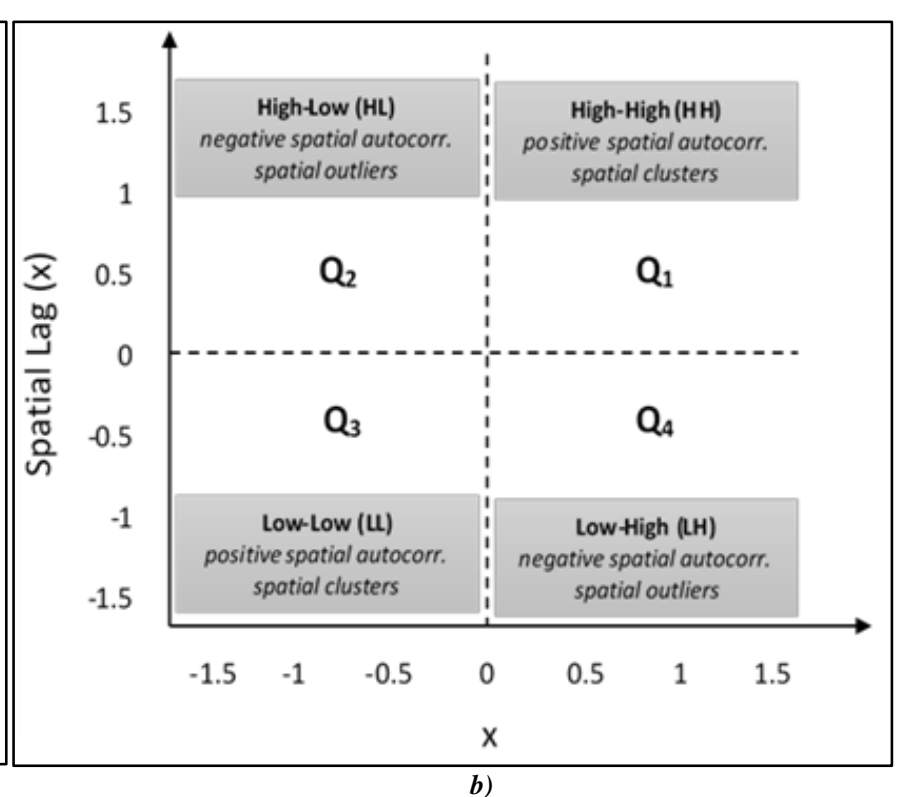

b)
Source: (a) Authors and (b) Günav Aktas, et al., 2019

people in the google map database. Google allows users to comment on the airports. Google can determine the general satisfaction only.

The data for the describing the main factors that affect the overall satisfaction of America Continents were derived from the Skytrax database. Skytrax is a platform where passengers voluntarily comment. The satisfaction with terminal seating areas, terminal cleaning and queuing was evaluated with scores from 1 to 5 and overall satisfaction from 1 to 8 . The number of airports in the Skytrax database are 58 that they were evaluated by 30 and above people.

\section{$\underline{\text { Analysis }}$}

Passengers' satisfaction levels with the airports of the Americas range from 2.5 to 4.7. The degrees of satisfaction are divided into 4 groups using the natural break method. Maps symbolized moderate satisfaction with yellow symbols, cold tones with high rank, and warm tones with low rank. For the mapping analysis MapInfo 16 program was used.
In order to explain spatial autocorrelation of passengers' satisfaction with the airports of the Americas global spatial autocorrelation ${ }^{1}$ analysis was used firstly. For this study, a spatial weights matrix based on queen contiguity was calculated. Figure 1 shows the connectivity graph that was prepared based on first degree neighborhood. After calculated weights matrix, Moran's I value ${ }^{2}$ was found as 0,176 (see Figure. 2. a) with a significant level of 0.05 .

Moran's I scatter plot for American Continents Airports is shown in Fig. 2. a. Quadrants of Moran's I is displayed in Fig2. b. When examined the scatter plot clear that Q1 and Q4 regions demonstrates similar airports in the American Continents in terms of Moran's I.

After fixed spatial autocorrelation between airports' satisfaction levels, local indicators of spatial association' (LISA) ${ }^{3}$ evaluated and drown LISA map. Global and local spatial autocorrelation

$$
\begin{aligned}
& { }^{1} \text { Moran's I is given in the following (Anselin; 1995): } \\
& I_{j}=\frac{n}{\sum_{i=1}^{n}\left(x_{i}-\bar{x}\right)^{2}} \frac{\sum_{i=1}^{n} w_{i j}\left(x_{j}-\bar{x}\right)\left(x_{i}-\bar{x}\right)}{\sum_{i=1}^{n} \sum_{j=1}^{n} w_{i j}}
\end{aligned}
$$

In equation (1), $n$ denotes the total number of observations measured in a different location and, xi and xj are the observation values measured in locations $i$ and $j$, respectively is the mean value of observations and wij is the element of the weight matrix which is calculated based on the determined distance matrix

${ }^{2}$ The Moran's I is bounded by -1 and 1. When Moran's I value is greater or less than 0, it means that there is a positive and a negative autocorrelation, respectively. The zero value of the Moran's I value indicates no spatial autocorrelation that means all randomness. In terms of clustering, positive spatial autocorrelation shows similar values being close to each other, negative spatial autocorrelation means that dissimilar values arise close to one another.

${ }^{3}$ According to Anselin, the LISA statistic has the following properties: $i$. shows the extent of significant spatial clustering for each location; ii. the sum of local statistics for all observations is proportional to a global indicator of spatial association. 
analysis is conducted with Moran's I statistics and GeoDa program was used.

A map of LISA shows significant clusters as highhigh (HH) / low-low (LL) means that high values are surrounded by high values /low values are surrounded by low values. The high-low (HL) and low-high (LH) are potential spatial outliers. This means that while a high value is surrounded by low values, a low value is surrounded by high values.

In order to determine how the general satisfaction of the passengers in the airports of the Americas is explained and whether there is a relationship between the level of general satisfaction and the number of daily flights, cleanliness, seating capacity and waiting time, a regression analysis was conducted.

The tourist satisfaction data were obtained from two different databases with regard to the airports of the Americas. The data obtained from Google showing overall satisfaction was used to analyze if there is a spatial distribution and spatial clustering as they are many in number. The data obtained from Skytrax allows analyzing the factors affecting the overall satisfaction, however the number of data is limited. The means of the two groups, independent of each other, were investigated because the data was supplied from two different platforms. For this, the t-test was employed. Independent Samples $t$ Test is a parametric method used to test the significance of the difference between two arithmetic means when each sample shows a normal distribution $(\mathrm{N} 1>30$; $\mathrm{N} 2>30$ ).

\section{Findings}

In this section, answers were sought for the four questions of the research. In other words, this section includes the findings regarding the spatial distribution of satisfaction with the airports of the Americas, the spatial clustering thereof, the explanation of overall satisfaction and whether there is a difference between the data obtained from different platforms.

\section{Spatial distribution of overall satisfaction with the airports of the Americas}

Understanding the distribution of passengers' satisfaction with America Continents, satisfaction levels of airports were mapped (see Figure 3).

Airports with the highest satisfaction level are Daniel Field, Dupage Airport, Wittman Regional Airport, Palmdale Regional/USAF Plant 42 Airport, and Base Aérea de Santos Airport. Four of these airports, except Base Aérea de Santos Airport in Brazil, are in North America. Out of these four airports in the United States, only

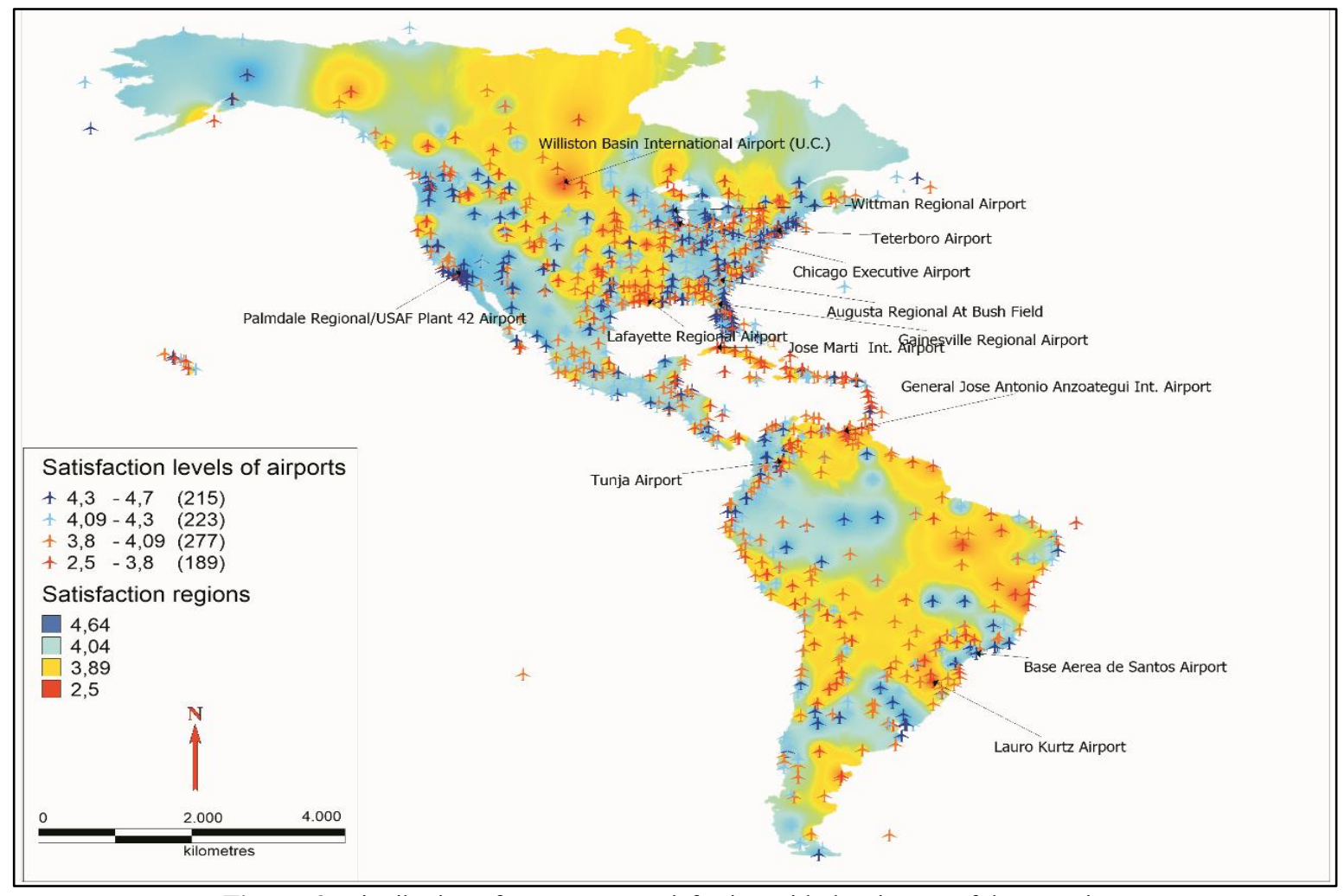

Source: Authors

Figure. 3. Distribution of passengers' satisfaction with the airports of the Americas 
Palmdale Regional/USAF Plant 42 Airport is located in the west of North America. There are 20 airports that are rated with 4.6 points, the second average of highest satisfaction. 12 of these airports are located in North America. The only airport rated with the lowest average of 2.5 points is Tunja Airport in Colombia. This is followed by Lauro Kurtz Airport in Brazil with 2.6 points. The third lowest average satisfaction score is 2.9 points. The airports with a 2.9 point average are Lafayette Regional Airport, La Guardia Airport, and Williston Basin International Airport in the United States, Jose Marti International Airport in Cuba, and General Jose Antonio Anzoategui International Airport in Venezuela.

It is stated that the areas shown in blue and light blue on the map include the airports with the highest passenger satisfaction level. It is understood that the airports in Newfoundland and Labrador, Ontario, Québec, and British Columbia states in the south of Canada in North America have a high level of passenger satisfaction. Besides, the states of Maryland, Pennsylvania, New York, Georgia, North Carolina, South Carolina, Virginia and Florida, along the north east, east and south east; Alaska, Washington, Oregon, California in the west; Texas and Mississippi in the south; Illinois, Indiana, Ohio, Minnesota, Wisconsin and Michigan in the central and northeast; Arizona in the south-west, and Colorado in the central part of the United States are notable for their airports with high passenger satisfaction. Mexico in Central
America, Colombia, Brazil, and Argentina in South America also have airports with high passenger satisfaction. It is observed that passenger satisfaction is also high at the airports in the Bahamas, an island country which is a part of Central America.

North Dakota and Louisiana states in the south of the United States as the regions where yellow and red colors are concentrated on the map attract attention as the regions with low passenger satisfaction. It is seen that Canada also has airports with low satisfaction scores. In case of South America, it is seen that there are airports with low satisfaction scores on the north, south and east coasts, especially in the south of Brazil.

\section{Spatial clustering of overall satisfaction with the airports of the Americas}

Although the spatial distribution of satisfaction in the America Continents has been determined, it is unknown whether there are any spatial clusters in terms of satisfaction levels. Figure. 4. displays that there is a spatial cluster for passengers' satisfaction with 158 airports with a significance level of 0.05 , and that there is no significant cluster in 745 airports.

When we look at the spatial autocorrelation map of the level of passenger satisfaction for the airports of the Americas, 64 airports, shown in red, constitute the spatial cluster indicating high-high satisfaction. It is seen that these airports are predominantly located on the east and west coasts

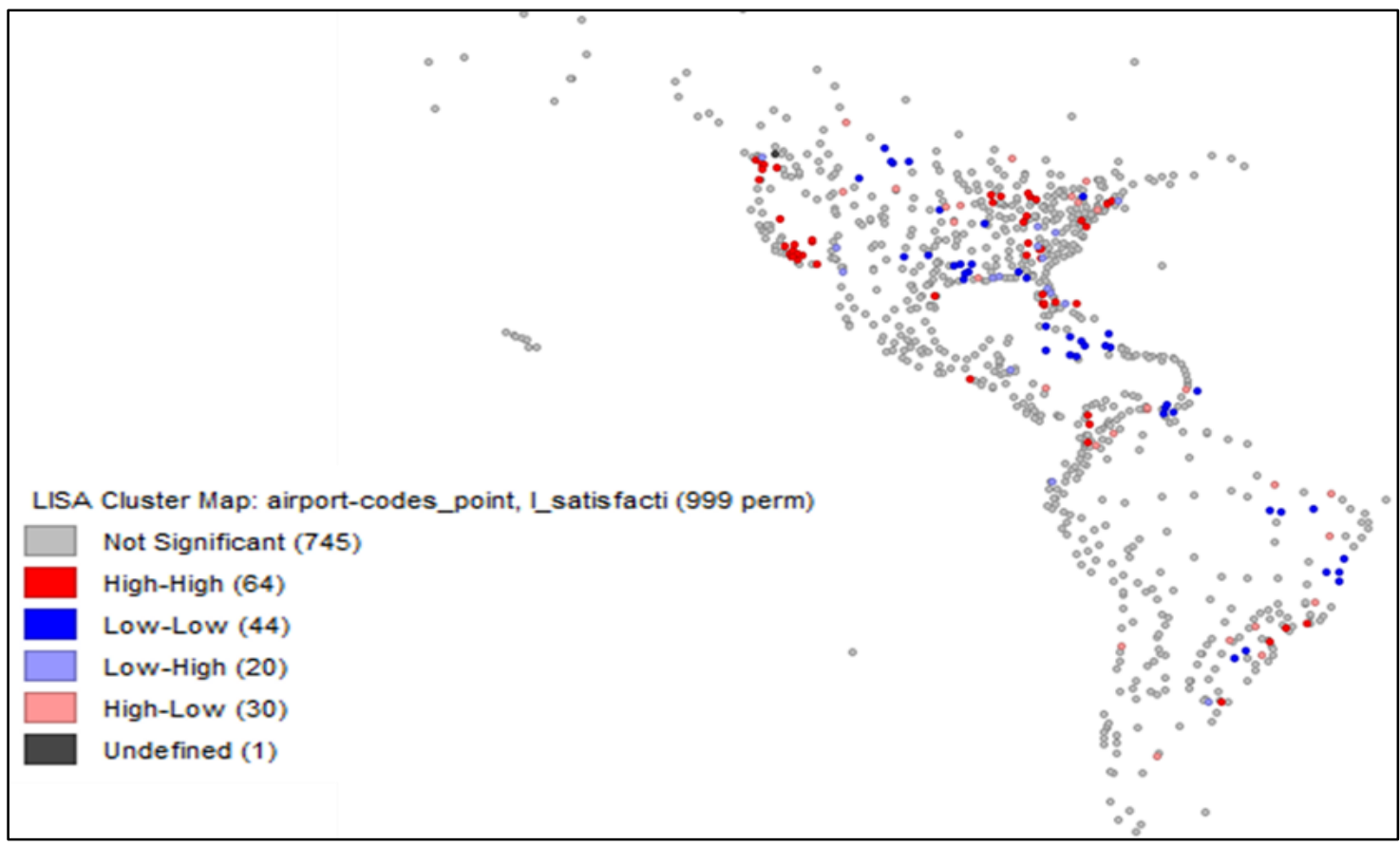

Figure. 4. LISA cluster map for the airports of the Americas 
of North America. 30 airports that have high satisfaction scores, however satisfaction score thereof is low in their neighbors, are shown in pink on the map. It is observed that the level of passenger satisfaction is low at 20 airports shown in light blue on the map, while it is high in their neighbors. The passenger satisfaction level of the 44 airports shown in blue, and the neighbors thereof, is low.

When Figure 4 is examined, it is understood that high-high satisfaction clusters are more common in North and Central America. Especially in the west and east of North America, high-high cluster is concentrated. In the inner and southern parts of North America, low-low clusters draw attention. It is observed that low-low cluster is concentrated on the islands in Central America. In the South American continent, there is a low-low spatial cluster in the north east of the continent and a high-high spatial cluster in the south east.

\section{Main factors that affect the overall satisfaction in the airports of the Americas}

The relationship between the overall satisfaction and the seating capacity, cleanliness, and queuing time variables of the airport passengers was tested with the help of Skytrax data. The overall satisfaction of the passengers was taken as the dependent variable. Descriptive statistics table for dependent variables and independent variables is given in Table 1.

Table 1. Descriptive Statistics of the variables for airport satisfaction

\begin{tabular}{|c|c|c|c|}
\hline & Mean & Std. Deviation & $\mathbf{N}$ \\
\hline Overall satisfaction & 3.069 & 1.18483 & 58 \\
\hline Terminal seating satisfaction & 2.6552 & .68956 & 58 \\
\hline $\begin{array}{l}\text { Terminal cleanliness } \\
\text { satisfaction }\end{array}$ & 3.1379 & 68693 & 58 \\
\hline Queuing times satisfaction & 2.5862 & .75008 & 58 \\
\hline
\end{tabular}

Source: Authors

When mean values are examined, it is seen that general satisfaction is 3.7 , terminal seating satisfaction is 2.6 , terminal cleanliness satisfaction is 3.1 , and queuing times satisfaction is 2.5 . The lowest satisfaction is for queuing time, whereas the highest satisfaction is for the overall satisfaction. The highest standard deviation among satisfaction indicators is seen in overall satisfaction (1.18). Satisfaction with queuing time (0.75) also has a high standard deviation.

Table 2. Model summary for airport satisfaction Model Summary

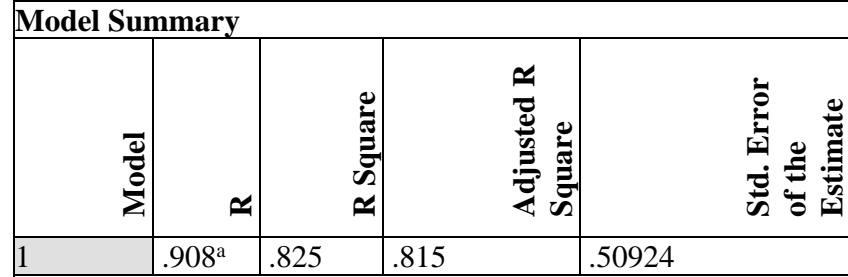

a. Predictors: (Constant), Queuing Times, Terminal Seating, Terminal Cleanliness

Source: Authors

Regression analysis was conducted to explain the satisfaction regarding the airports. According to the results of the analysis, the variables of seating capacity, cleanliness and queuing time explain $81.5 \%$ of overall satisfaction in evaluating the overall satisfaction for the airports (see Table 2).

Table 3. ANOVA for airport satisfaction

\begin{tabular}{|c|c|c|c|c|c|c|}
\hline \multicolumn{2}{|c|}{ Model } & 苛 & 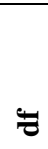 & 胥 & 工 & 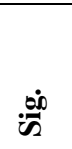 \\
\hline \multirow[t]{3}{*}{1} & Regression & 66.014 & 3 & 22.005 & $\begin{array}{l}84.85 \\
4\end{array}$ & $\begin{array}{l}.000 \\
\mathrm{~b}\end{array}$ \\
\hline & Residual & 14.003 & 54 & .259 & & \\
\hline & Total & 80.017 & 57 & & & \\
\hline \multicolumn{7}{|c|}{ a. Dependent Variable: Overall } \\
\hline
\end{tabular}

When Table 3 is examined, it is seen that at least one of the variables of seating capacity, cleanliness, and queuing time has an effect on overall satisfaction $(p<0.05)$. The effects of these variables on overall satisfaction are given in Table 4 .

Table 4 sets forth that the variables of cleanliness and queuing time $(p<0.05)$ have a significantly positive effect on overall satisfaction. It is seen that seating capacity does not have a significant effect on overall satisfaction ( $p>0.05$ ). The most effective independent variable on overall satisfaction is queuing times.

Whether there is a difference between Skytrax and Google users' evaluation of airports.

Table 4. Factors affecting overall satisfaction with airports

\begin{tabular}{|c|c|c|c|c|c|}
\hline \multirow[t]{2}{*}{ Model } & \multicolumn{2}{|c|}{ Unstandardized Coefficients } & \multirow{2}{*}{$\begin{array}{l}\text { Standardized } \\
\text { Coefficients } \\
\text { Beta } \\
\end{array}$} & \multirow[t]{2}{*}{$\mathrm{t}$} & \multirow[t]{2}{*}{ Sig. } \\
\hline & B & Std. Error & & & \\
\hline (Constant) & -0.837 & 0.322 & & -2.601 & 0.012 \\
\hline Terminal Seating & 0.216 & 0.149 & 0.126 & 1.456 & 0.151 \\
\hline Terminal Cleanliness & 0.554 & 0.154 & 0.321 & 3.593 & 0.001 \\
\hline QueuingTimes & 0.863 & 0.143 & 0.547 & 6.050 & 0.000 \\
\hline
\end{tabular}


Table 5. $\mathrm{t}$ test for Skytrax and Google users' assessment on the airports

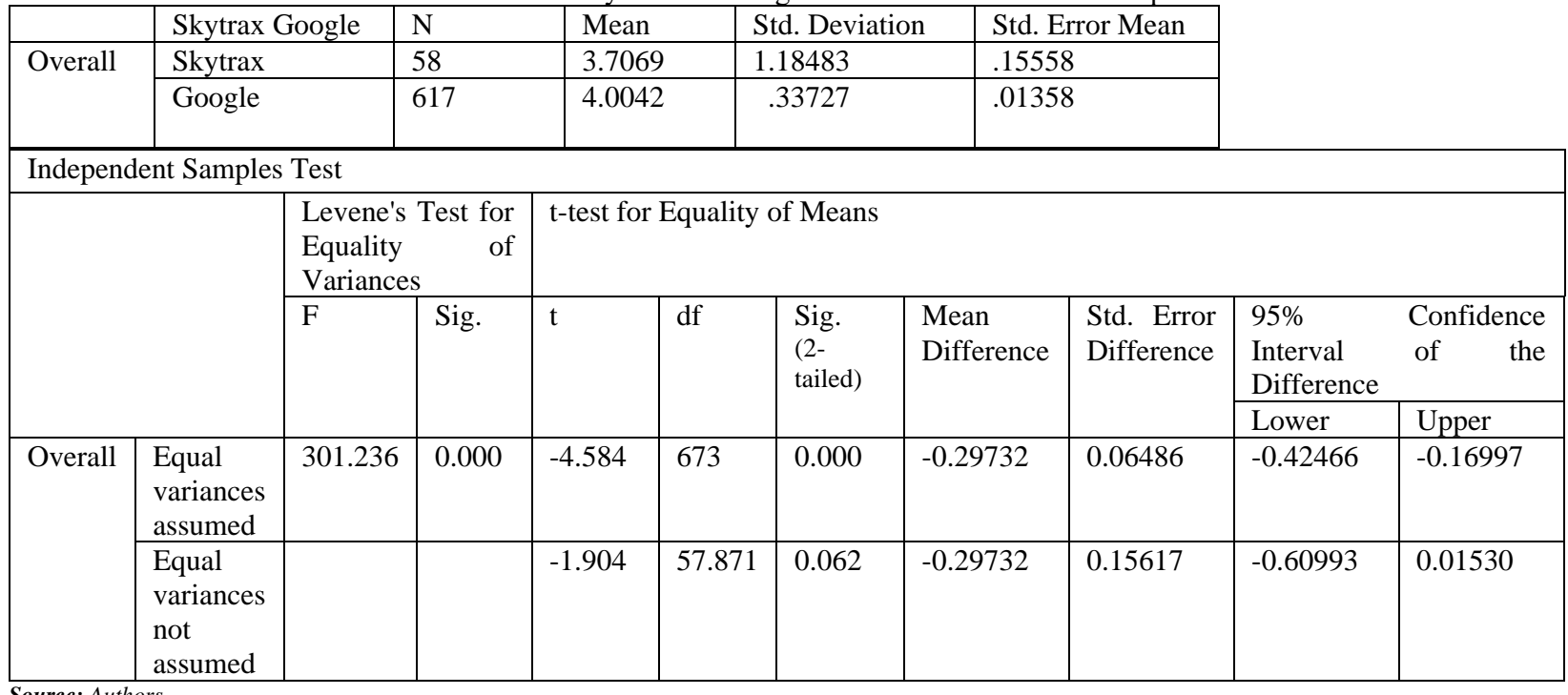

Two different groups can be used to test whether numerical data differ significantly from each other. This study assessed the Skytrax and Google users' opinions on overall satisfaction regarding the airports. According to the Independent Samples t Test, it was examined whether there is a significant difference between these two groups' overall satisfaction assessments for the airports (Table 5).

The descriptive statistics show that the mean overall satisfaction levels of both data groups $($ Skytrax mean $=3.71$, Google mean $=4.00)$ is close to each other. This reveals that both Skytrax and Google users have expressed the same level of satisfaction with American airports.

The results of $t$ test revealed that two user-groups independent of each other were not homogeneously distributed $(p<0.05)$. Accordingly, based on the difference between the groups, it is found that there is no difference between Skytrax users' and Google users' opinions regarding overall satisfaction with airports (Equal variances not assumed, $(\mathrm{p}=0.65>0.05)$.

\section{Discussion and Conclusion}

Tourist satisfaction is very important in terms of loyalty to a destination, and this is explained as revisit and recommendation intentions. Fuchs and Weiermair (2004) argue that many tourism destinations consider tourist satisfaction as one of the most important sources of competitive advantages. Yen-Lun Su (2004) states that "the purpose of measuring customer satisfaction is to evaluate the quality of current management practices and to determine the improvement aspects". Park and Jung (2011) conducted a study on the airport service quality perceptions of transfer passengers at Incheon International Airport and found that passengers who are satisfied with the airport service quality are more likely to reuse the airport and recommend it to other passengers.

In the study, the tourist satisfaction regarding the airports in the Americas was analyzed by obtaining data from two different platforms. The distribution and clustering of satisfaction with the airports were analyzed with the data obtained from Google. It is observed that satisfaction with airports is high in the east and west of North America, while it is low in the central parts. For Central America, satisfaction appears to be high in the west of the continent and low in the east. For South America, the satisfaction appears to be high in the northeast, northwest and also in the south west coasts, while it is low in other parts. Previous studies for Europe and Asia also show that tourist satisfaction with airports creates a spatial pattern in the continents.

The spatial pattern in the spatial distribution of airports suggests the question of whether there is spatial autocorrelation. The analyzes performed revealed that the airport satisfaction creates spatial autocorrelation in the Americas. This shows that the airports in certain parts of the continents have similar characteristics. This similarity affects the distribution of satisfaction. In fact, this situation reveals the necessity of determining the factors affecting satisfaction regarding airports. 
Skytrax data were used to determine the variables that affect the satisfaction at airports. It is clear from the research that the general satisfaction is explained by airport cleanliness, seating capacity and queuing times. The results obtained are consistent with the researches conducted on the European and Asian continents (Günay Aktaş et al., 2020: 508; Yavuz et al., 2020: 233-234). Besides, queuing time was found to be the independent variable which affects the satisfaction the most for the three continents. Airport cleanliness is the second variable affecting overall satisfaction in all three continents. In their research on 33 airports, Bogicevic et al. (2013) concluded that airport cleaning is the key to passenger satisfaction.

The airport seating capacity in the Americas does not affect overall satisfaction unlike the European and Asian continents. This result can be interpreted in the sense that the airport seating capacities in the Americas are sufficient or they have more capacity than other continents. Correia et al. (2008), Ahmadpour et al. (2014) and Batra (2014) concluded in their studies that seating comfort has a significant effect on visitors.

Although there are variables in the Skytrax platform that can explain airport satisfaction, the number of data to be used in the research is limited. The lack of statistical difference between the overall satisfaction values obtained from Skytrax and Google platforms shows that measures should be taken to reduce the queuing times to increase satisfaction at airports. Then, measures should be taken for airport cleanliness. The improvement that will affect satisfaction in the third place is increasing the seating capacity. Since the research was conducted for airports for which adequate number of opinions were reported, it was conducted for a limited number of airports. The study can be evaluated more comprehensively for more airports in the future with the increase in the number of opinions and the formation of the opinions regarding the airports for which no comments have been made.

The majority of the opinions of the passengers in this study is from pre-Covid-19 period. Repeating a similar research within the scope of post-pandemic opinions may bring a new initiative. If research is carried out only with new data, queuing time is likely to affect the satisfaction less, and the cleanliness is likely to be affected more, due to the decrease in the number of passengers.

\section{References}

Ahmadpour, N., Lindgaard, G., Robert, J.-M., \& Pownall, B. (2014). The thematic structure of passenger comfort experience and its relationship to the context features in the aircraft cabin. Ergonomics, 57(6), 801-815.

Anselin, L. (1995). Local indicators of spatial associationLISA. Geographical Analysis, 27, 93-115.

Aşık, N. A. (2019). Yerli ve yabancı yolcuların havalimanı hizmet kalitesi algıları: İstanbul Havalimanı Örneği. Journal of Tourism and Gastronomy Studies, 7(4), 2612-2629.

Batra, A. (2014). The role of airport servicescape: The transient community perspective. Tourism Dimensions, 1(1), 27-37.

Bogicevic, V., Yang, W., Bilgihan, A., \& Bujisic, M. (2013). Airport service quality drivers of passenger satisfaction. Tourism Review, 68 (4) pp. $3-18$.

Chao, C. C., Lin, H. C., \& Chen, C. Y. (2013). Enhancing airport service quality: A case study of Kaohsiung International Airport. Journal of the Eastern Asia Society for Transportation Studies, 10, 22352254 .

Çolak, S., \& Doğan, Ü. (2015). Havaalanı hizmet kalitesinin müşteri memnuniyetine etkisi: Kayseri Havalimanı örneği. https://docplayer.biz.tr/19025548-Havaalanihizmet-kalitesinin-musteri-memnuniyetineetkisi-kayseri-havalimani-ornegi.html.

Correia, A. R., Wirasinghe, S. C., \& de Barros, A. G. (2008). Overall level of service measures for airport passenger terminals. Transportation Research Part A: Policy and Practice, 42(2), 330346.

Dimitriou, D., \& Aparicio, S. (2018). Comparative evaluation of airports productivity toward tourism development. Cogent Business \& Management, 5(1), 1464378.

Douglas, A., Lubbe, B., \& Zambellis, J. (2001). An Application of the airport service quality model in South Africa. Journal of Air Transport Management, 17, 224.

Erdoğan, D. (2020). Havaalanı hizmet kalitesinin önemperformans analiziyle değerlendirilmesi: Gaziantep Havalimanı örneği. Journal of Aviation Research, 2(2), 82-100.

European Commission (2011). Europe's airports 2030: Challenges ahead. (MEMO 11/857).

Fuchs, M., \& Weiermair, K. (2004). Destination benchmarking: An indicator-system's potential for exploring guest satisfaction. Journal of travel research, 42(3), 212-225. 
Graham, A., Papatheodorou, A., \& Forsyth, P. (2008). Aviation and tourism. Implications for Leisure Travel. Ashgate Publishing, Ltd.

Günay Aktaş, S., Kantar, Y. M., Yavuz, N., \& Olgaç, S. (2020). Satisfaction with Asian airports. The Council for Australasian Tourism and Hospitality Education 2020 Conference Proceeding, Auckland, New Zealand, 505-508.

Günay Aktas, S., Kumtepe, E. G., Kantar, Y. M., Ulukan, I. C., Aydin, S., Aksoy, T., \& Er, F. (2019). Improving gender equality in higher education in Turkey. Applied Spatial Analysis and Policy, $12(1), 167-189$

Işıldak, B., \& Tunca, M. Z. (2018). Havalimanı hizmetlerinde müşteri memnuniyetini etkileyen faktörler üzerine bir araştırma. Süleyman Demirel University Journal of Faculty of Economics and Administrative Sciences, 23 (1), 241-255.

Kazda, A. (2000). Airport design and operation. In; A. Kazda ve R.E. Caves (Editors) Passenger Terminals (ss.245-263). UK: Pergamon Elsevier Science.

Khan, S. A. R., Qianli, D., SongBo, W., Zaman, K., \& Zhang, Y. (2017). Travel and tourism competitiveness index: The impact of air transportation, railways transportation, travel and transport services on international inbound and outbound tourism. Journal of Air Transport Management, 58, 125-134.

Kim, M. H., Park, J. W., \& Choi, Y. J. (2016). A study on the effect of airport choice attributes on airport users' satisfaction and behavioural intentions: The case of Gimpo International Airport. Journal of Airport Management, 10(2), 145-157.

Koo, T. T., Rashidi, T. H., Park, J. W., Wu, C. L., \& Tseng, W. C. (2017). The effect of enhanced international air access on the demand for peripheral tourism destinations: Evidence from air itinerary choice behaviour of Korean visitors to Australia. Transportation Research Part A: Policy and Practice, 106, 116-129.

Kuyucak, F. (2007). Havaalanlarında değer odakl yönetim yönelimli bilgi sistemlerinin kullanılması ve Atatürk Havalimanı Terminal İsletmeciliği uygulaması. (Doctoral dissertation). Eskişehir: Anadolu University, Social Sciences Institute.

Moon, H., Yoon, H. J., \& Han, H. (2017). The effect of airport atmospherics on satisfaction and behavioral intentions: testing the moderating role of perceived safety. Journal of Travel \& Tourism Marketing, 34(6), 749-763. DOI:10.1080/10548408.2016.1223779

Okumuş, A., \& Asil, H. (2007). Havayolu taşımacılığında yerli ve yabancı yolcuların memnuniyet düzeylerine göre beklentilerinin incelenmesi. Kocaeli University Journal of the Institute of Social Sciences, 13 (1), 152 - 175

Park, J. W., \& Jung, S. Y. (2011). Transfer passengers' perceptions of airport service quality: A case study of Incheon International Airport. International Business Research, 4 (3), 75-82.

Rendeiro, R., \& Cesar, M. (2006). Tourism service quality begins at the airport. Tourism Management, 27, (2006), 874-877.

Sezgin, E., \& Yavuz, N. (2018). Aktarma (transfer) yoğun ve üç yıldızlı iki havalimanı: Atatürk ve Dubai Havalimanları yolcularının hizmet algıları üzerine bir çalışma. Turan-Sam, 10(49), pp 66-77.

Tan, H. (2008). Havaalanlarının turizmdeki etkinliği ve verimliliği: Veri Zarflama Analizi (Dea) kullanılarak Türkiye Cumhuriyeti havalimanlarında ölçümü. (Specialization Thesis). Ankara: T.C. Kültür ve Turizm Bakanlığ Dış İlişkiler ve AB Koordinasyon Dairesi Başkanlığı.

Tuncer, B., \& Cavcar E. (2014). Havalimanı terminal hizmet kalitesini etkileyen faktörlerin belirlenmesi. Akademik Sosyal Arastırmalar Dergisi, Yıl: 2, Sayı: 6, Eylül 2014, s. 183-211.

Wiltshire, J. (2017). Airport competition: reality or myth? Journal of Air Transpor Management, https://doi.org/10.1016/j.jairtraman.2017.03.006.

Yavuz, N., Olgac, S., Günay Aktas, S., \& Mert Kantar, Y. (2020). Passenger satisfaction in European. In; Travel and Tourism: Sustainability, Economics, and Management Issues. Ed: Coşkun, İ.O., Othman, N. Aslam, M., and Lew. A. Springer: Singapur Airports. Travel and Tourism: Sustainability, Economic and Management Issues. Springer, 223-234.

Yen-Lun $\quad \mathrm{Su}, \quad$ A. (2004). Customer satisfactionmeasurement practice in Taiwan hotels. International Journal of Hospitality Management, 23(4), 397-408. 


\title{
INFO PAGE
}

\section{TOURIST SATISFACTION WITH AMERICAN CONTINENT AIRPORTS}

\begin{abstract}
Tourist satisfaction is very important in terms of destination loyalty as revisit and recommendation intentions. The development of airline transportation has led to an increase in the average time spent by tourists during the destination process by shortening the transportation time. The purpose of this study is to determine the spatial distribution of passenger satisfaction levels at airports in the Americas. For this purpose, data for determining tourist satisfaction has been obtained from two different platforms. In order to determine the general satisfaction level at the airports, the data of 904 airports where 30 or more users made comments were taken into consideration in the google map database. Satisfaction distribution and clustering regarding airports were evaluated with the data obtained from Google. Mapping analysis was conducted using the spatial analysis method to determine the satisfaction levels of the tourists. Maplnfo 16 program was used for mapping analysis. Satisfaction levels from American airports vary between 2.5 and 4.7. In addition, whether the airport satisfaction is spatial autocorrelation has been tested using the GeoDa program. Analyzes have revealed that airport satisfaction creates spatial autocorrelation in America. It is observed that satisfaction is high in airports in the east and west of North America and low in the middle parts. Satisfaction for Central America has been found to be high in the west of the continent and low in the east. Satisfaction levels for South America are high in the northeast, northwest, and also southwest coasts, while it is low in other parts. This situation shows that airports located in certain regions of the continent have similar characteristics. Skytrax data were used to determine the variables affecting satisfaction at airports. Because there is no statistical difference between the general satisfaction values obtained from Skytrax and google platforms. In the study, the data of 58 airports, which are 30 or more evaluated in the Skytrax database, were used. Accordingly, the variables affecting general satisfaction were explained by airport cleanliness, seating capacity, and waiting times. In addition, it was determined that the independent variable that affects satisfaction the most is the waiting time in the queue. This situation shows that measures should be taken to reduce the waiting time in the queue to increase satisfaction at airports. As a result, it is important to determine tourist satisfaction, to evaluate the quality of current practices, and to identify improvement aspects. High overall satisfaction at airports will increase the likelihood of tourists to reuse these airports and recommend them to other passengers, and will positively affect destination loyalty.
\end{abstract}

Keywords: Amerikan Continents Airports, Satisfaction Map, Terminal Cleaning, Queuing Times, Terminal Seating Facilities, Overall satisfaction, Spatial Outocorellation

\section{Authors} Supervision, Project administration, Funding acquisition,

Eşref Ay: Formal analysis, Data Curation, Writing - Original Draft, Visualization,

Author statement: Author(s) declare(s) that All procedures performed in studies involving human participants were in accordance with the ethical standards of the institutional and/or national research committee and with the 1964 Helsinki declaration and its later amendments or comparable ethical standards.

This paper does not required ethics committee report Justification: The methodology of this study does not require an ethics committee report. 